\title{
Piagam Madinah dan Spiritnya dalam Undang-Undang Dasar (UUD) 1945
}

\author{
Elkhairati \\ Institut Agama Islam Negeri (IAIN) Curup \\ elkhairati9@gmail.com
}

\begin{abstract}
This paper aims to look at the existence of the Medina Charter in terms of history, content and authenticity and how it is spiritual in the 1945 Constitution. This study takes the form of literature with a content analysis approach. Data collection techniques in this study are carried out by collecting magazines, journals and books and utilizing internet to collect data related to research. This study concludes that the Charter of Medina contains the Islamic Shari'a as a law, is democratic in nature. If observed carefully, it will be seen the spirit of the Medina Constitution in the 1945 Constitution as the basis of the State of Indonesia. The concrete form is reflected in the points of the articles of the 1945 Constitution. This proves that even though the Republic of Indonesia is not an Islamic state, it does not mean that this country ignores Islamic shari'a.
\end{abstract}

Keywords: Medina Charter, State, Constitution

\begin{abstract}
Abstrak
Tulisan ini bertujuan untuk melihat keberadaan Piagam Madinah dari sisi historis, isi dan autentitas serta bagaimana spriritnya dalam UUD 1945. Kajian ini berbentuk kepustakaan dengan pendekatan content analysis. Teknik pengumpulan data dalam penelitian ini dilakukan dengan cara mengumpulkan majalah, jurnal dan buku-buku serta memanfaatkan internet untuk mengumpulkan data yang berhubungan dengan penelitian. Penelitian ini berkesimpulan bahwa Piagam Madinah berisikan syari'at Islam sebagai undang-undang, bersifat demokratis. Jika diamati secara jeli, akan terlihat spirit Konstitusi Madinah dalam UUD 1945 sebagai dasar Negara Indonesia. Bentuk konkritnya tercermin dalam butiran pasal-pasal UUD 1945.Ini membuktikan meskipun Negara Republik Indonesia bukanlah negara Islam namun, itu bukan berarti negara ini mengabaikan syari'at Islam.
\end{abstract}

Kata Kunci: Piagam Madinah, Negara, Konstitusi

Al-Istinbath : Jurnal Hukum Islam Vol. 4, No. 1, 2019; 51-68

p-issn: 2548-3374; e-issn: 2548-3382; DOI: 10.29240/jhi.v4i1.776

Available online at: http://journal.staincurup.ac.id/index.php/alistinbath 


\section{Pendahuluan}

Sekitar lima belasan abad yang lalu, tetapnya tahun pertama Hijriah/622 M sebelum masyarakat dunia mengenal konstitusi tertulis, Rasulullah SAW telah membuat "Piagam Madinah"1 yang dikenal sebagai konstitusi tertulis pertama di dunia. ${ }^{2}$

Piagam Madinah bertujuan membentuk suatu masyarakat yang harmonis yang terdiri dari berbagai suku dan agama (Islam, Yahudi dan Musyrik) dalam suatu negara Madinah. ${ }^{3}$ Piagam ini, disamping mengatur hubungan dalam negeri

${ }^{1}$ Para ahli sejarah, menyebut naskah politik yang dibuat Muhammad SAW itu dengan nama yang bermacam-macam. W. Montgemery Watt menamainya "The Constitution of Madina". R.A. Nicholson "Charter", Majid Khaduri "Treaty". Philip K. Hitti “Agreement". Zainal Abidin Ahmad dengan "Piagam". "Al-shabifah" adalah nama yang disebut dalam naskah itu sendiri, tertulis sebanyak delapan kali. Selain nama itu, di dalam naskah, tertulis sebutan "Kitab" dua kali. Kata Treaty dan Agreement menunjuk kepada isi naskah. Kata Charter dan piagam lebih menunjukkan kepada surat resmi yang berisi pernyataan tentang suatu hal. Kata Constitution menunjuk kepada kedudukan naskah itu sebagai dokumen resmi yang berisi pokok-pokok kenegaraan. Kata Shahifa semakna dengan Charter dan piagam. Dalam pada itu kata Kitab lebih menunjukkan kepada tulisan (tentang suatu hal). Ismatullah dalam bukunya Gagasan Pemerintahan Modern dalam Konstitusi Madinah, menyebutnya dengan "Konstitusi Madinah". Lihat Dedy Ismatullah, Gagasan Pemerintahan Modern dalam Konstitusi Madinah, (Bandung: Atadbir dan Sahifa, 2006):74.

${ }^{2}$ Penyebutan konstitusi tertulis pertama di dunia ini bukan tanpa dasar. Sebab konstitusi Aristoteles Athena yang ditulis pada papirus, ditemukan oleh seorang misionaris Amerika di Mesir baru pada tahun 1890 dan diterbitkan pada tahun 1891, itupun tidak dianggap sebuah konstitusi. Tulisan-tulisan hukum lainnya pada perilaku masyarakat kuno telah ditemukan, tetapi tidak dapat digambarkan sebagai konstitusi. Sementara itu, sejarahnya konstitusi Amerika Serikat baru disusun beberapa tahun setelah pernyataan kemerdekaan Amerika Serikat (AS) yang ditandatangani pada tahun 1776.Itupun mengalami banyak perubahan (amandemen).Namun "Piagam Madinah" (Madinah Charter) adalah konstitusi tertulis pertama mendahului Magna Carta, yang berarti Piagam Besar, disepakati di Runnymede, Surrey pada tahun 1215. Landasan bagi konstitusi Inggris ini pula yang menjadi rujukan Amerika membuat konstitusi yang selama ini dianggap oleh Barat sebagai "dokumen penting dari dunia Barat" dan menjadi rujukan/model banyak negara di dunia. Kehadiran "Piagam Madinah" nyaris 6 abad mendahului Magna Charta, dan hampir 12 abad mendahului Konstitusi Amerika Serikat ataupun Prancis. Lihathttp://www.hidayatullah.com/spesial/ragam/read/2014/11/15/33214/piagam-madinahkonstitusi-tertulis-pertama-di-dunia-1.html

${ }^{3}$ Keberadaan negara Madinah dapat diamati dengan menggunakan dua pendekatan. Pertama, pendekatan normatif Islam yang menekankan pada pelacakan ayat al-Qur'an dan sunnah Nabi yang mengisyaratkan adanya praktek pemerintahan yang dilakukan oleh Nabi dalam rangka siyasah sar'iyah. Kedua, pendekatan deskriptif historis dengan mengidentikkan tugastugas yang dilakukan oleh Nabi di bidang muamalah sebagai tugas-tugas Negara dan pemerintahan. Hal ini diukur dari sudut pandangan teori-teori politik dan ketatanegaraan. Unsur-unsur sebuah negara telah terpenuhi; yaitu population, territory and a government. Lihat http://agenmakalah. blogspot.co.id/2015/01/pemerintahan-di-masa-nabi-negara-madinah. html

Di samping itu, menurut Ahmad Ibrahim Abu Sinn, keberadaan Negara Madinah dapat dibuktikan dengan ilmu manajemen. Dia berargumen bahwa struktur pemerintahan pada masa Rasulullah SAW sudah mencerminkan sebuah organisasi pemerintahan yang baik, semua orang ditempatkan berdasarkan keahlian masing-masing. Pemberian wewenang dan tanggung jawab 
(antar warga negara), juga mengatur hubungan luar negeri (Negara Madinah dengan luar Madinah) agar mereka tidak berkomplot dengan kafir Quraisy untuk menyerang Madinah.

Tulisan ini, mencoba membicarakan tentang Piagam Madinah atau "Sabifah al-Madinah" dengan mengajukan pertanyaan; apa yang melatarbelakangi lahirnya Piagam Madinah, bagaimana mekanisme penyusunan draf Piagam Madinah, bagaimana keautentikan Piagam Madinah itu sendiri, bagaimana hubungannya dengan penegakan syari'at Islam, dan bagaimana pula kaitannya dengan UUD negara Indonesia? Untuk menjawab pertanyaan di atas, digunakan kajian kepustakaan dengan metode konten analysis (telaah isi)meliputi langkahlangkah reduksi, verifikasi dan inferensi.

Masyarakat Madinah terdiri dari bermacam suku, golongan dan agama. Golongan-golongan itu antara lain para sahabat Rasulullah SAW, kaum musyirikin Madinah, dan kaum Yahudi. Kaum musyrikin Madinah adalah kabilah-kabilah asli Madinah. Diantara mereka ada yang masih ragu-ragu meninggalkan agama nenek moyang mereka, namun mereka tidak memusuhi Islam. Sebagian kaum musyrikin yang lain diam-diam memusuhi Islam. Diantara mereka yang diam-diam memusuhi Islam adalah Abdullah bin Ubay. Ia menampakkan keislaman pada Rasulullah SAW, namun dalam hatinya memusuhi dan merongrong umat Islam. Sebelumnya Abdullah bin Ubay akan diangkat jadi raja di Madinah untuk menjatuhkan suku Aus dan Khazraj. Namun dengan kedatangan Islam, Abdullah bin Ubay batal diangkat menjadi raja. Hal ini yang menyebabkan ia membenci kedatangan Rasulullah SAW dan diam-diam memusuhi Islam. ${ }^{4}$

Selain Abdullah bin Ubay satu orang lagi yang menampakkan permusuhan pada Islam adalah Abu Amir dari suku Aws. Dia sampai bergabung dengan Quraisy Mekkah untuk menyerang umat Islam. ${ }^{5}$ Yahudi pun pada dasarnya tidak senang akan kedatangan Islam yang berdampak pada hilangnya potensi mereka untuk merebutkan dominasi di Madinah. Pada awalnya suku Aws dan Khazrah bersatu untuk menyingkirkan Yahudi dari Madinah. Namun dengan tipu daya Yahudi dapat memecah bela kedua suku ini untuk perang, sehingga Yahudi dapat legalitas untuk tinggal di Madinah dan mendapatkan keuntungan dari perseteruan diantara mereka. ${ }^{6}$ Untuk itu, kaum Yahudi

linear dengan setara kepemimpinan dalam level manajemen, untuk lebih jelasnya lihat struktur aparatur pemerintahan periode Rasulullah SAW, lihat Ahmad Ibrahim Abu Sinn, Manajemen Syariah Sebuah Kajian Historis dan Kontemporer, penerjemah Dimyaudin Djuwaini, judul asli, "AlIdarah fi al-Islam”, (Jakarta: Raja Grapindo, 2006): 101.

${ }^{4}$ H. M. As'ad Bashori, Sejarah Kebudayaan Islam, (Surabaya: Prima Media, 2008):22.

${ }^{5}$ Martin Lings, Muhammad, (Jakarta: Serambi, 2007): 271.

${ }^{6}$ Bashori, 2008: 19. 
menerima kedatangan Islam hanya karena alasan politis yang dengan kedatangan Islam bisa dimanfaatkan untuk kepentingan Yahudi.

Atas dasar itulah demi mewujudkan negara yang kokoh Nabi Muhammad SAW mempersatukan seluruh lapisan golongan masyarakat Madinah dengan diikat oleh Perjanjian yang disebut Piagam Madinah dan diharapkan dapat memperkuat posisi negara Madinah sebagai pusat pemerintahan Islam. ${ }^{7}$

Dalam literatur yang ditemukan, dikatakan bahwa naskah perjanjian itu dibuat setelah Nabi SAW tiba di Madinah sebelum perang Badar dan ditulis dalam dua peristiwa. Pertama dibuat oleh Nabi antara kelompok Muhajirin dan Anshar di rumah Anas bin Malik. Sedangkan naskah kedua dibuat oleh Nabi SAW dengan melibatkan kaum Yahudi dan juga terjadi sebelum perang Badar. Kemudian kedua naskah tersebut dipersatukan oleh para penulis sejarah menjadi satu naskah sebagaimana yang dikenal sekarang. ${ }^{8}$

Sedangkan yang menandatangani Piagam Madinah adalah tokoh kaum Muhajirin dan Anshar, serta tokoh Yahudi dan Nasrani dari Bani Qainuqa, Bani Nadir, dan Bani Quraidah. Mereka menyatakan kesiapan untuk membangun Madinah dan menjaga Madinah dari serangan musuh-musuhnya. ${ }^{9}$

Dengan demikian dapatlah dikatakan bahwa Piagam Madinah merupakan sebuah "Konstitusi" yang berarti Undang-undang dasar. ${ }^{10}$ Istilah konstitusi memang ditujukan kepada surat atau dokumen resmi yang berisi pokok-pokok kenegaraan, dan ciri itu terdapat dalam Piagam Madinah.

\section{Pembahasan}

Pengakuan tentang keautentikan naskah piagam Madinah, sejauh yang dapat ditelusuri dari berbagai tulisan, tampaknya sudah merupakan asumsi dasar para ilmuwan baik dari kalangan muslim maupun non muslim. W. Montgomery Watt, misalnya, menyatakan bahwa secara umum dokumen tersebut diakui autentik. Petunjuk tentang keautentikan konstitusi tersebut, menurut Arent Jan Wensinsh ditemukan pada sumber hukum yang kedua (al-hadis), dikeluarkan oleh kedua guru besar hadis yang sangat otoritatif; al-Bukhari dan Muslim dalam

${ }^{7}$ Menurut Abd Mun'im Khamis, pembuatan piagam Madinah merupakan perencanaan operasional menurut ilmu manajemen yang dijalankan oleh Rasulullah SAW berdasarkan petunjuk dan pertolongan Allah SWT. Lihat Muhammad Mun'im Khamis, al-Idarah fi Shadr alIslam, (Kairo: Dirasah Muqaranah al-Majlis al-Ala Lisysyu'un al-Islam, 1974): 59. Dengan demikian, sebelum orang Barat mengangung-agungkan teori manajemen modern, Rasullulah SAW sudah mempraktekannya pada masa pemerintahannya.

${ }^{8}$ Ismatullah, 2006: 132.

${ }^{9}$ Budi Sudrajat, Sejarah Kebudayaan Islam,(Jakarta: Yudhistira, 2007): 23.

${ }^{10}$ Istilah konstitusi berasal dari bahasa Inggris "Constitution" dengan arti undang-undang dasar. Lihat John M. Echos dan Hassan Sadzily, Kamus Inggris Indonesia, Jakarta: Gramedia, 2010), Cet ke-29: 141. 
babFadhail al-Madinah. Juga dokumen tersebut disebutkan oleh kedua guru besar hadis yang lain, yaitu Abu Daud dan al-Nasai dalam kedua sunannya. ${ }^{11}$

Di dalam hadis-hadis tersebut dijelaskan, bahwa ketika Nabi SAW tiba di Madinah, pada saat itu terdapat tiga kelompok pemeluk agama, yaitu Islam, agama berhala (paganisme) dan pemeluk agama Yahudi. Komunitas muslim diwakili oleh dua kelompok; Mubajirin dan Anshar. Pemeluk Yahudi terdiri dari Bani Quraizah, Bani Nadhir, dan Bani Qainuqa. Untuk mencegah terjadinya konflik horizontal antar agama, etnik dan kesukuan, maka Rasulullah SAW menyusun konstitusi Madinah, sebuah naskah perjanjian bersama yang berisikan kesepakatan-kesepakatan demi terciptanya stabilitas dalam kerangka membangun masyarakat Madinah. ${ }^{12}$

Menurut Shahih Ahmad al-Ali, bahwa otentisitasnya tercermin pada susunan redaksionalnya. Teksnya terdiri dari kalimat-kalimat pendek, banyak pengulangan yang ditulis pada satu pola yakni pada penggunaan kata-kata dan ungkapan yang sesuai dengan masa itu serta menggambarkan semangat zaman. Namun, sekalipun kalimatnya pendek dan singkat, isi dan spirit yang terkandung di dalamnya cukup padat. ${ }^{13}$

Otentisitasnya juga dapat dilihat dari sisi ilmu hadis. Karena lahirnya piagam itu merupakan hasil perbuatan Nabi SAW, maka ia juga termasuk hadis. Ini didukung oleh para ulama hadis, seperti al-Bukhari, Muslim, Abu Daud dan Ahmad, juga para penulis sejarah, semisal Ibn Ishaq.

Ada hadis yang diriwayatkan oleh Ahmad menceritakan:

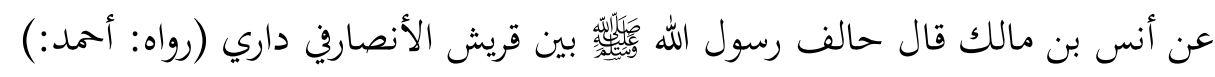

Dari Anas bin Malik, dia berkata: "Sesunggubnya Nabi SAW telah membuat perjanjian persekutuan antara Quraisy dan Anshar di rumabku". (HR. Ahmad) ${ }^{14}$

Dalam riwayat lain, Muhammad Ibn Ishaq menyampaikan:

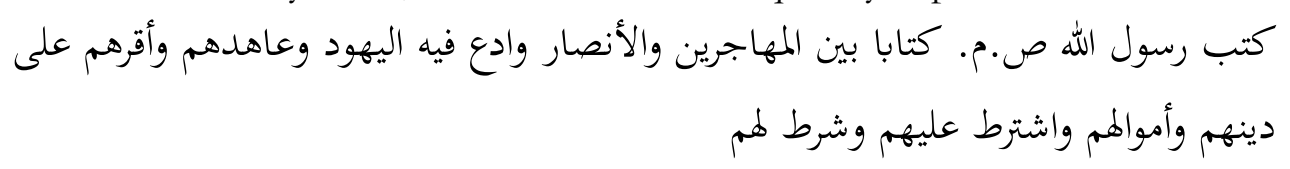

Rasulullab SAW telab menuliskan suatu (perjanjian) antara Mubajirin dan Anshar dan mengajak kaum Yabudi dan membuat perjanjian dengan mereka, dan ia mengakui mereka

\footnotetext{
${ }^{11}$ Ismatullah , 2006:131.

${ }^{12}$ Ismatullah, 2006: 131.

${ }^{13}$ Ismatullah, 2006: 133.

${ }^{14}$ Abi al-Fida' al-Hafidz Ibn Katsir al-Dimasyqy, al-Bidayah wa al-Nihayah, (Bairut: Dar al-Kutub al-Ilmiah, 2001), Juz III: 235. Hadis yang semakna juga diriwayatkan oleh al-Bukhari,
} Muslim, Abu Daud. 
tetap dalam agama mereka dan harta benda mereka, dan ia juga menetapkan kewajibankewajiban atas mereka serta menjamin bak-bak mereka". ${ }^{15}$

Secara eksplisit, dalam hadis-hadis tidak disebutkan teks piagam Madinah. Tetapi, yang ada hanyalah teks yang mengatakan adanya perjanjian persekutuan baik antara Mubajirin dan Anshar maupun antara kaum muslim dengan non muslim Madinah. Isi teks piagam Madinah yang ditemukan sekarang merupakan versi Ibn Ishaq, Ibn Sallam dan versi Muhammad Hamidullah. Ketiga versi tersebut, terutama antara versi Ibn Ishaq dan versi Ibn Sallam terdapat perbedaan redaksional dan isinya. Versi Ibn Sallam tidak selengkap versi Ibn Ishaq, sedangkan antara versi Ibn Ishaq dengan versi Muhammad Hamidullah tidak terdapat perbedaan isi, hanya perbedaan kecil dalam redaksi dan kata-kata yang digunakan. Perbedaan terjadi karena naskah perjanjian tersebut tidak diperoleh hanya dari satu sumber serta dikenal luas di kalangan para imam hadis dan para penulis sejarah. ${ }^{16}$

Dalam teks asli Piagam Madinah tidak terdapat pasal-pasal, A.J. Winsick yang pertama kali membaginya dalam pasal-pasal (47 pasal) dalam bukunya Mohammed en de joden te Madina. ${ }^{17}$

Kandungan "Piagam Madinah" terdiri daripada 47 pasal, 23 pasal membicarakan tentang hubungan antara umat Islam yaitu; antara Kaum Anshar dan Kaum Muhajirin. Sedangkan 24 pasal lain membicarakan tentang hubungan umat Islam dengan umat lain, termasuk Yahudi. Selengkapnya teks yang berbunyi: ${ }^{18}$

\section{Mukaddimah}

Dengan nama Tuhan Yang Maha Pengasih lagi Maha Penyayang "Inilah Piagam Tertulis dari Nabi Muhammad SAW di kalangan orang-orang yang beriman dan memeluk Islam (yang berasal) dari Quraisy dan Yatsrib, dan orangorang yang mengikuti mereka, mempersatukan diri dan berjuang bersama mereka"

\section{Pembentukan Umat}

Pasal 1 Sesungguhnya mereka satu bangsa negara (umat), bebas dari (pengaruh dan kekuasaan) manusia.

\footnotetext{
${ }^{15}$ Ibn Katsir al-Dimasyqy, 2001: 235.

${ }^{16}$ Ismatullah, 2006: 136.

${ }^{17}$ http://mafahim-azhari.blogspot.co.id/2008/11/piagam-madinah-tanpa-hukumislam.html piagam.html

${ }^{18}$ http:/ / islahilwathon.blogspot.co.id/2014/06/makalah-fiqih-siyasah-konsep-
} 


\section{Hak Asasi Manusia}

Pasal 2 Kaum Mubajirin dari Quraisy tetap mempunyai hak asli mereka, saling tanggung-menanggung, membayar dan menerima uang tebusan darah (diyat) karena suatu pembunuhan, dengan cara yang baik dan adil di antara orang-orang beriman.

Pasal 3 1). Banu 'Awf (dari Yathrib) tetap mempunyai hak asli mereka, tanggung menanggung uang tebusan darah (diyat). 2). Dan setiap keluarga dari mereka membayar bersama uang tebusan dengan baik dan adil di antara orang-orang beriman.

Pasal 4 1). Banu Sa'idah (dari Yathrib) tetap atas hak asli mereka, tanggung menanggung uang tebusan mereka. 2). Dan setiap keluarga dari mereka membayar bersama akan uang tebusan dengan baik dan adil di antara orang-orang beriman.

Pasal 5 1). Banul-Harts (dari suku Yathrib) tetap berpegang atas hak-hak asli mereka, saling tanggung-menanggung untuk membayar uang tebusan darah (diyat) di antara mereka. 2). Setiap keluarga (tha'ifah) dapat membayar tebusan dengan secara baik dan adil di kalangan orangorang beriman.

Pasal 6 1). Banu Jusyam (dari suku Yathrib) tetap berpegang atas hak-hak asli mereka, tanggung-menanggung membayar uang tebusan darah (diyat) di antara mereka. 2). Setiap keluarga (tha'ifah) dapat membayar tebusan dengan secara baik dan adil di kalangan orang-orang beriman.

Pasal 7 1). Banu Najjar (dari suku Yathrib) tetap berpegang atas hak-hak asli mereka, tanggung-menanggung membayar uang tebusan darah (diyat) dengan secara baik dan adil. 2). Setiap keluarga (tha'ifah) dapat membayar tebusan dengan secara baik dan adil di kalangan orang beriman.

Pasal 8 1). Banu 'Amrin (dari suku Yathrib) tetap berpegang atas hak-hak asli mereka, tanggung-menanggung membayar uang tebusan darah (diyat) di antara mereka. 2). Setiap keluarga (tha'ifah) dapat membayar tebusan dengan secara baik dan adil di kalangan orang-orang beriman.

Pasal 9 1). Banu An-Nabiet (dari suku Yathrib) tetap berpegang atas hak-hak asli mereka, tanggung-menanggung membayar uang tebusan darah (diyat) di antara mereka. 2). Setiap keluarga (tha'ifah) dapat membayar tebusan dengan secara baik dan adil di kalangan orang-orang beriman.

Pasal 10 1). Banu Aws (dari suku Yathrib) berpegang atas hak-hak asli mereka, tanggung-menanggung membayar uang tebusan darah (diyat) di antara mereka. 2). Setiap keluarga (tha'ifah) dapat membayar tebusan dengan secara baik dan adil di kalangan orang-orang beriman. 


\section{Persatuan Seagama}

Pasal 11 Sesungguhnya orang-orang beriman tidak akan melalaikan tanggung jawabnya untuk memberi sumbangan bagi orang-orang yang berhutang, karena membayar uang tebusan darah dengan secara baik dan adil di kalangan orang-orang beriman.

Pasal 12 Tidak seorang pun dari orang-orang yang beriman dibolehkan membuat persekutuan dengan teman sekutu dari orang yang beriman lainnya, tanpa persetujuan terlebih dahulu dari padanya.

Pasal 13 1). Segenap orang-orang beriman yang bertaqwa harus menentang setiap orang yang berbuat kesalahan, melanggar ketertiban, penipuan, permusuhan atau pengacauan di kalangan masyarakat orang-orang beriman. 2). Kebulatan persatuan mereka terhadap orang-orang yang bersalah merupakan tangan yang satu, walaupun terhadap anak-anak mereka sendiri.

Pasal 14 1). Tidak diperkenankan seseorang yang beriman membunuh seorang beriman lainnya karena lantaran seorang yang tidak beriman. 2). Tidak pula diperkenankan seorang yang beriman membantu seorang yang kafir untuk melawan seorang yang beriman lainnya.

Pasal 15 1). Jaminan Tuhan adalah satu dan merata, melindungi nasib orangorang yang lemah. 2). Segenap orang-orang yang beriman harus jaminmenjamin dan setia kawan sesama mereka terhadap (gangguan) manusia lain.

\section{Persatuan Segenap Warga Negara}

Pasal 16 Bahwa sesungguhnya kaum-bangsa Yahudi yang setia kepada (negara) kita, berhak mendapatkan bantuan dan perlindungan, tidak boleh dikurangi haknya dan tidak boleh diasingkan dari pergaulan umum.

Pasal17 1). Perdamaian dari orang-orang beriman adalah satu 2). Tidak diperkenankan segolongan orang-orang yang beriman membuat perjanjian tanpa ikut sertanya segolongan lainnya di dalam suatu peperangan di jalan Tuhan, kecuali atas dasar persamaan dan adil di antara mereka.

Pasal 18 Setiap penyerangan yang dilakukan terhadap kita, merupakan tantangan terhadap semuanya yang harus memperkuat persatuan antara segenap golongan.

Pasal 19 1). Segenap orang-orang yang beriman harus memberikan pembelaan atas tiap-tiap darah yang tertumpah di jalan Tuhan. 2). Setiap orang beriman yang bertaqwa harus berteguh hati atas jalan yang baik dan kuat.

Pasal 20 1). Perlindungan yang diberikan oleh seorang yang tidak beriman (musyrik) terhadap harta dan jiwa seorang musuh Quraisy, tidaklah diakui. 2). Campur tangan apapun tidaklah diizinkan atas kerugian seorang yang beriman. 
Pasal 21 1). Barangsiapa yang membunuh seorang yang beriman dengan cukup bukti atas perbuatannya harus dihukum bunuh atasnya, kecuali kalau wali (keluarga yang berhak) dari si terbunuh bersedia dan rela menerima ganti kerugian (diyat). 2). Segenap warga yang beriman harus bersatu mengutuk perbuatan itu, dan tidak diizinkan selain daripada menghukum kejahatan itu.

Pasal 22 1). Tidak dibenarkan bagi setiap orang yang mengakui piagam ini dan percaya kepada Tuhan dan hari akhir, membantu orang-orang yang salah, dan memberikan tempat kediaman baginya. 2). Siapa yang memberikan bantuan atau memberikan tempat tinggal bagi pengkhianat-pengkhianat negara atau orang-orang yang salah, akan mendapatkan kutukan dan kemurkaan Tuhan di hari kiamat nanti, dan tidak diterima segala pengakuan dan kesaksiannya.

Pasal 23 Apabila timbul perbedaan pendapat di antara kamu di dalam suatu persoalan, maka kembalikanlah penyelesaiannya (hukum) pada Tuhan dan (keputusan) Muhammad SAW.

\section{Golongan Minoritas}

Pasal 24 Warga negara (dari golongan) Yahudi memikul biaya bersama-sama dengan kaum beriman, selama negara dalam peperangan.

Pasal 25 1). Kaum Yahudi dari suku 'Awf adalah satu bangsa-negara (umat) dengan warga yang beriman. 2). Kaum Yahudi bebas memeluk agama mereka, seperti kaum Muslimin bebas memeluk agama mereka. 3). Kebebasan ini berlaku juga terhadap pengikut-pengikut/sekutu-sekutu mereka, dan diri mereka sendiri. 4). Kecuali kalau ada yang mengacau dan berbuat kejahatan, yang menimpa diri orang yang bersangkutan dan keluarganya.

Pasal 26 Kaum Yahudi dari Banu Najjar diperlakukan sama seperti kaum Yahudi dari Banu' $A w f$ di atas.

Pasal 27 Kaum Yahudi dari Banul-Harts diperlakukan sama seperti kaum Yahudi dari Banu' Awf di atas

Pasal 28 Kaum Yahudi dari Banu Sa'idah diperlakukan sama seperti kaum Yahudi dari Banu 'Awf di atas.

Pasal 29 Kaum Yahudi dari Banu Jusyam diperlakukan sama seperti kaum Yahudi dari Banu 'Awf di atas.

Pasal 30 Kaum Yahudi dari Banu Aws diperlakukan sama seperti kaum Yahudi dari Banu 'Awf di atas.

Pasal 31 1). Kaum Yahudi dari Banu Tsa'labah, diperlakukan sama seperti kaum Yahudi dari Banu 'Awf di atas 2). Kecuali orang yang mengacau atau berbuat kejahatan, maka ganjaran dari pengacauan dan kejahatannya itu menimpa dirinya dan keluarganya.

Pasal 32 Suku Jafnah adalah bertali darah dengan kaum Yahudi dari Banu Tsa'labah, diperlakukan sama seperti Banu Tsa'labah. 
Pasal 33 1). Banu Syuthaibah diperlakukan sama seperti kaum Yahudi dari Banu 'Awf di atas. 2). Sikap yang baik harus dapat membendung segala penyelewengan.

Pasal 34 Pengikut-pengikut/sekutu-sekutu dari Banu Tsa'labah, diperlakukan sama seperti Banu Tsa'labah.

Pasal 35 Segala pegawai-pegawai dan pembela-pembela kaum Yahudi, diperlakukan sama seperti kaum Yahudi.

\section{Tugas Warga Negara}

Pasal 36 1). Tidak seorang pun diperbolehkan bertindak keluar, tanpa izin Muhammad SAW 2). Seorang warga negara dapat membalaskan kejahatan luka yang dilakukan orang kepadanya 3). Siapa yang berbuat kejahatan, maka ganjaran kejahatan itu menimpa dirinya dan keluarganya, kecuali untuk membela diri 4). Tuhan melindungi orangorang yang setia kepada piagam ini.

Pasal 37 1). Kaum Yahudi memikul biaya negara, sebagai halnya kaum Muslimin memikul biaya negara 2). Di antara segenap warga negara (Yahudi dan Muslim) terjalin pembelaan untuk menentang setiap musuh negara yang memerangi setiap peserta dari piagam ini 3). Di antara mereka harus terdapat saling nasihat-menasihati dan berbuat kebajikan, dan menjauhi segala dosa 4). Seorang warga negara tidaklah dianggap bersalah, karena kesalahan yang dibuat sahabat/sekutunya 5). Pertolongan, pembelaan, dan bantuan harus diberikan kepada orang/golongan yang teraniaya.

Pasal 38 Warga negara kaum Yahudi memikul biaya bersama-sama warga negara yang beriman, selama peperangan masih terjadi.

\section{Melindungi Negara}

Pasal 39 Sesungguhnya kota Yatsrib, Ibukota Negara, tidak boleh dilanggar kehormatannya oleh setiap peserta piagam ini.

Pasal 40 Segala tetangga yang berdampingan rumah, harus diperlakukan seperti diri-sendiri, tidak boleh diganggu ketenteramannya, dan tidak diperlakukan salah.

Pasal 41 Tidak seorang pun tetangga wanita boleh diganggu ketenteraman atau kehormatannya, melainkan setiap kunjungan harus dengan izin suaminya.

\section{Pimpinan Negara}

Pasal 42 1). Tidak boleh terjadi suatu peristiwa di antara peserta piagam ini atau terjadi pertengkaran, melainkan segera dilaporkan dan diserahkan penyelesaiannya menurut (hukum) Tuhan dan (kebijaksanaan) utusanNya, Muhammad SAW 2). Tuhan berpegang teguh kepada piagam ini dan orang-orang yang setia kepadanya. 
Pasal 43 Sesungguhnya (musuh) Quraisy tidak boleh dilindungi, begitu juga segala orang yang membantu mereka.

Pasal 44 Di kalangan warga negara sudah terikat janji pertahanan bersama untuk menentang setiap agresor yang menyerang kota Yastrib.

\section{Politik Perdamaian}

Pasal 45 1). Apabila mereka diajak pada pendamaian (dan) membuat perjanjian damai (treaty), mereka tetap bersedia untuk berdamai dan membuat perjanjian damai 2). Setiap kali ajakan pendamaian seperti demikian, sesungguhnya kaum yang beriman harus melakukannya, kecuali terhadap orang (negara) yang menunjukkan permusuhan terhadap agama (Islam) 3). Kewajiban atas setiap warga negara mengambil bahagian untuk perdamaian itu.

Pasal 46 1). Dan sesungguhnya kaum Yahudi dari Aws dan segala sekutu dan simpatisan mereka, mempunyai kewajiban yang sama dengan segala peserta piagam untuk kebaikan (pendamaian) itu 2). Sesungguhnya kebaikan (pendamaian) dapat menghilangkan segala kesalahan.

\section{Penutup}

Pasal 47 1). Setiap orang (warga negara) yang berusaha, segala usahanya adalah untuk dirinya. 2). Sesungguhnya Tuhan meridhai semua peserta piagam ini, yang menjalankannya dengan jujur dan sebaik-baiknya 3). Sesungguhnya tidaklah boleh piagam ini dipergunakan untuk melindungi orang-orang yang zalim dan bersalah 4). Sesungguhnya (mulai saat ini), orang-orang yang bepergian (keluar), adalah aman 5). Dan orang yang menetap adalah aman pula, kecuali orang-orang yang zalim dan berbuat salah 6). Sesungguhnya Tuhan melindungi orang (warga negara) yang baik dan bersikap taqwa (waspada) 7). Dan (akhirnya) Muhammad adalah Pesuruh Tuhan, semoga Tuhan mencurahkan salawat dan kesejahteraan atasnya.

Piagam Madinah merupakan panduan hukum yang bertujuan membentuk suatu masyarakat yang harmonis dalam Negara Madinah dengan berbagai suku dan agama. Disamping itu, juga mengatur hubungan dalam dan luar negeri.

Dalam Pasal 35 dinyatakan: Kelompok-kelompok keturunan Yahudi berlaku ketentuan sama sebagaimana yang berlaku bagi Kaum Yahudi itu sendiri. Ketentuan ini sebatas menjalankan ritual ibadah dan tradisi mereka. Hal ini ditegaskan dalam pasal 25: Kaum Yahudi Bani 'Auf bersama dengan warga yang beriman adalah satu umat. Kedua belah pihak, kaum Yahudi dan kaum Muslimin, bebas memeluk agama masing-masing. Jadi, dalam urusan ritual ibadah dan tradisi maka masing-masing pemeluk bebas menjalankan syari'at mereka, seperti: beribadah, makan, minum, menikah, dan lainnya. Tetapi jika 
mengatur interaksi antar umat di dalam bermasyarakat dan bernegara maka hukum Islam yang diterapkan. Pasal 23 dan 42 dengan tegas menyatakan bahwa jika ada perselisihan di tengah umat maka diselesaikan oleh Muhammad SAW menurut hukum Allah SWT.

Pasal 23 berbunyi: Apabila kamu berselisih tentang sesuatu, penyelesaiannya menurut (ketentuan) Allah 'Azza wa Jalla dan (keputusan) Muhammad SAW. Pasal 42: Bila terjadi suatu peristiwa atau perselisihan di antara pendukung Piagam ini, yang dikhawatirkan menimbulkan bahaya, diserahkan penyelesaiannya menurut (ketentuan) Allah 'Azza wa Jalla, dan (keputusan) Muhammad SAW.

Dengan demikian kaum Yahudi diperlakukan sebagai kafir drimmi, kafir dzimmi adalah orang kafir yang tunduk kepada Negara Islam yang menerapkan hukum Islam. Bentuk ketundukannya dengan membayar jiayah kepada negara sehingga jiwa, harta dan kehormatannya dilindungi.Hal ini dikuatkan oleh Pasal 16: Sesungguhnya orang Yahudi yang mengikuti kita berhak atas pertolongan dan santunan, sepanjang (mukminin) tidak terzalimi dan ditentang (olehnya).

Tetapi jika mereka melakukan pembunuhan diberlakukan hukuman qishash atau diyat bagi pembunuh, seperti bunyi Pasal 21: Barang siapa yang membunuh orang beriman dan cukup bukti atas perbuatannya, harus dihukum bunuh, kecuali wali si terbunuh rela (menerima diyat). Segenap orang beriman harus bersatu dalam menghukumnya, karena ayat al-Qur'an mengatakan:

Hai orang yang beriman, diwajibkan atas kamu qishash berkenan dengan orang yang dibunub; orang merdeka dengan orang merdeka, bamba dengan hamba dan wanita dengan wanita. Maka barangsiapa yang mendapat suatu pema'afan dari saudaranya, bendaklah (yang mema'afkan) mengikuti dengan cara yang baik, dan hendaklah (yang diberi ma'af) membayar (diyat) kepada yang memberi ma'af dengan cara yang baik (pula)... (QS:2: 178).

Untuk diyat pembunuh yang dimaafkan oleh keluarga korban adalah 100 unta atau 1.000 dinar, sebagaimana bunyi hadis dari Amar bin Sy'aib:

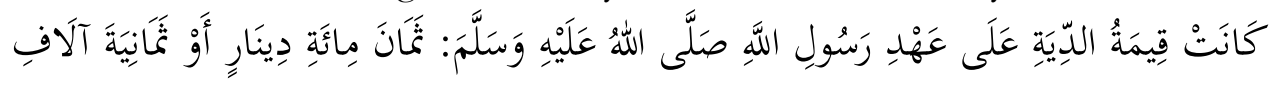

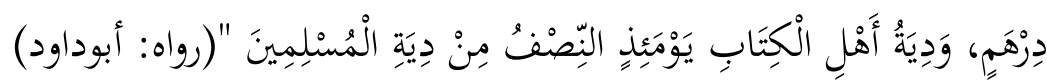

Adalah harga diyat di masa Rasulullah SAW 800 dinar atau 8000 dirbam, dan diyat abli kitab di ketike itu adalah separuh dari diyat orang muslim. (HR. Abu Daud) ${ }^{19}$

${ }^{19} \mathrm{CD}-\mathrm{ROOM}$, al-Makhtabah asy-Syamilah. Hadis No: 4542. Dalam hadis yang lain dikatakan bahwa di dalam (pembunuhan) jiwa itu terdapat diyat berupa 100 unta dan terbadap pemilike emas (ada kewajiban) sebanyak 1.000 dinar." (HR. an-Nasa'i dari Amru bin Hazem).Untuk penjelasan diyat lebih lengkapnya lihat Said Sabiq, Figh as-Sinnah, (Bairut: Dar al-Fikr, 1992), Jilid 2: $465-481$. 
Diyat terhadap anggota tubuh tergantung cedera yang dialami. An-Nasa'i dari az-Zuhri dari Abu Bakar bin Muhammad bin Amru bin Hazem dari bapaknya dari kakeknya, bahwa Rasulullah SAW telah menulis sepucuk surat kepadanya:

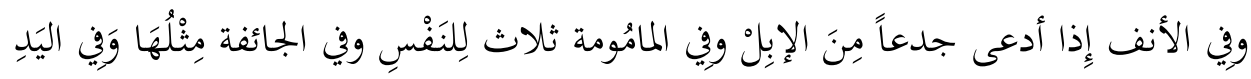

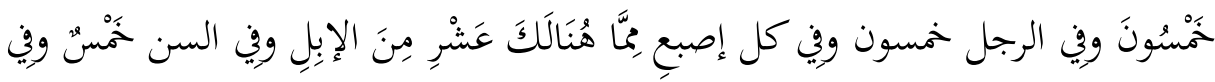

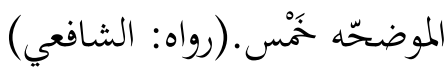

Dan terbadap bidung, apabila diambil batangnya maka diyat (kompensasi) seekor unta, terbadap otak sepertiga diyat, terbadap bagian dalam tubuh ada sepertiga diyat, terbadap satu tangan dikenakan 50 unta, satu kaki juga 50 unta, pada masing jari dikenakan 10 unta, lidah dikenakan lima unta, dan terbadap luka yang kelihatan tulangnya juga dikenakan lima ekor unta.(HR. Asy-Syafi'i). ${ }^{20}$

Walaupun Islam mengakomodasi kepentingan masyarakat Madinah yang plural, tetapi tetap berpegang pada hukum Islampasal 23 dan 42 menyatakan bahwa setiap perselisihan dikembalikan kepada hukum Allah SWT dan rasulNya.

Dalam Pasal 22 dikatakan bahwa setiap mukmin yang menyetujui isi alShahifah ini dan beriman kepada Allah SWT dan hari akhir, tidak di benarkan menolong pelaku kejahatan dan tidak pula membelanya, maka sesungguhnya ia akan mendapat kutukan dan murka dari Allah di hari kiamat dan tidak ada suatu tebusan yang dapat diterima daripadanya.

Kemudian dalam Pasal 36 dijelaskan bahwa tidak seorang pun dari mereka (penduduk Madinah) dibolehkan keluar kecuali dengan izin Nabi Muhammad SAW. Tetapi seseorang tidak boleh dihalangi menuntut haknya (balas) karena dilukai. Dan bahwa siapa yang melakukan kejahatan berarti ia melakukan kejahatan terhadap dirinya dan keluarganya, kecuali bila orang itu melakukan aniaya. Sesungguhnya Allah memperhatikan ketentuan yang paling baik dalam hal ini.

Setelah di teliti dan dikaji secara mendalam, naskah perjanjian tersebut mengandung beberapa prinsip yaitu; prinsip orang-orang muslim dan mukmin adalah umat yang satu dan antara mereka dan non-muslim adalah juga umat yang satu (semua manusia adalah umat yang satu); prinsip persatuan dan persaudaraan; prinsip persamaan; prinsip kebebasan; prinsip tolong-menolong dan membela yang teraniaya; prinsip hidup bertetangga; prinsip keadilan; prinsip musyawarah; prinsip pelaksanaan hukum dan sanksi hukum; prinsip kebebasan beragama dan hubungan antar pemeluk agama (hubungan antar bangsa/internasional); prinsip pertahanan dan perdamaian; prinsip amar makruf

\footnotetext{
${ }^{20}$ CD-ROOM, Hadis No: 369.
} 
dan nahi munkar; prinsip kepemimpinan; prinsip tanggung jawab pribadi dan kelompok; dan, prinsip ketakwaan dan ketaatan (disiplin).

Prinsip-prinsip tersebut sangat modern untuk masa itu. Bahkan untuk dewasa ini pun tetap relevan karena nilai-nilainya yang universal. Sebab prinsipprinsip tersebut telah menjadi tuntutan berbagai bangsa di dunia agar tegak dalam hidup bermasyarakat dan bernegara, yaitu tatanan masyarakat yang demokratis, adil dan damai. Maka amatlah tepat komentar Nurcholis Madjid berikut ini; "Bunyi naskah konstitusi itu sangat menarik. Ia memuat pokokpokok pikiran yang dari sudut tinjauan modern pun mengagumkan. Dalam konstitusi itulah untuk pertama kalinya dirumuskan ide-ide yang kini menjadi pandangan hidup modern di dunia, seperti kebebasan beragama, hak setiap kelompok untuk mengatur hidup sesuai dengan keyakinannya, kemerdekaan hubungan ekonomi antar golongan, dan umum, yaitu partisipasi dalam usaha pertahanan bersama menghadapi musuh dari luar.",21

Oleh karena itu, Pickthal menilai kelahiran dan fungsi naskah perjanjian itu, menjadi bukti bahwa Nabi menampilkan diri sebagai sosok pemimpin untuk menetapkan dan mengatur kepentingan umum sebagai undang-undang Negara (the constitution of the state).Sekalipun Nabi tidak pernah mengatakan bahwa beliau telah mendirikan Negara, dan tidak satupun ayat al-Qur'an yang memerintahkan beliau agar mendirikan Negara. Tetapi karena ajaran Islam memadukan antara urusan agama dan dunia, diperlukan adanya lembaga dan pemimpin untuk melaksanakannya, dan Nabi SAW sendiri telah mempraktekannya.22 Kepemimpinan Nabi selaku kepala Negara adalah untuk mengatur segala persoalan dan memikirkan kemaslahatan umat secara keseluruhan, dalam rangka pelaksanaan Siyasah Syariyah.

Sedangkan praktek pemerintahan Nabi Muhammad SAW di bidang hukum adalah kedudukan beliau sebagai hakim untuk menyelesaikan perselisihan yang timbul di kalangan masyarakat Madinah, dan menetapkan hukuman terhadap pelanggar perjanjian. Kedudukan sebagai hakim dan tugas ini pernah beliau wakilkan kepada sahabat, penunjukan salah satu sahabat menjadi hakim, merupakan bukti praktek pemerintahan Nabi SAW di bidang pranata sosial hukum.

Menurut Madjid Khadduri, apabila syari'at Islam berperan dalam pemerintahan umat Islam, maka ia disebut nomokrasi. Demikian juga

\footnotetext{
${ }^{21}$ Nurcholish Madjid, "Cita-cita Politik Kita", dalam Aspirasi Umat Islam Indonesia, (Jakarta: Leppenas, 1983): 11.

${ }^{22} \mathrm{Hal}$ ini bertolak belakang dengan pernyataan Nurcholish Madjid yang berusaha memisahkan antara agama dengan negara. Menurutnya negara adalah salah satu kehidupan duniawi yang berdiensi rasional dan kolektif, sedangkan agama merupakan aspek kehidupan yang dimensinya adalah spiritual dan bersifat pribadi. Lihat HM. Rasyidi, Koreksi tehadap Nurcholish Madjid tentang Sekularisasi, (Jakarta: Bulan Bintang, 1972): 55.
} 
pemerintahan Nabi. Sedangkan bagi al-Maududi, sistem pemerintahan yang demikian ia sebut teo-demokrasi. Sebab, disamping syari'at yang diwahyukan Tuhan sebagai pemenang kedaulatan tunggal mengenai berbagai ketentuan hukum, kekuasaan Tuhan berada di tangan umat untuk melaksanakan syari'at. Karenanya ia membatasi kedaulatan rakyat. Namun umat memperoleh kedudukan utama untuk memusyawarahkan masalah-masalah yang belum jelas hukumnya dalam syariat Islam.

Dalam Negara Madinah itu memang ada dua kedaulatan, yaitu kedaulatan syari'at Islam sebagai undang-undang Negara itu, dan kedaulatan umat. Syariat Islam sebagai undang-undang di satu segi ia membatasi kekuasaan umat untuk membuat undang-undang mengenai hukum sesuatu bila penjelasan hukumnya sudah jelas dalam nash syariat. Tapi di segi lain ia memberi hak kebebasan kepada umat untuk menetapkan hukum suatu hal yang belum jelas hukumnya, memerintahkan kepada umat agar memusyawarahkan setiap urusan mereka, yaitu urusan yang belum jelas hukumnya, dalam nash syari'at. Ini telah dicontohkan oleh Nabi Muhammad SAW. Jadi Negara Madinah itu adalah Negara yang berdasarkan syari'at Islam, tetapi ia memberi hak bermusyawarah dan berijtihad kepada umat. Dengan demikian corak Negara Madinah adalah Negara berasaskan syari'at Islam, dan bersifat demokratis.

Konstitusi Madinah telah tercermin dalam konstitusi Indonesia. Bahwa Negara Indonesia adalah Negara kesatuan yang berideologi Pancasila dan UUD 1945 sebagai dasar struktur Negara. Sila pertama adalah Ketuhanan Yang Maha Esa. Bab XI UUD 1945 menyatakan bahwa Negara menjamin kemerdekaan tiap-tiap penduduk untuk memeluk agamanya masing-masing dan beribadat menurut agama dan kepercayaannya.

Ketentuan UUD 1945 tersebut bertentangan dengan arah sekularisasi dan teokrasi homogen. Demokrasi menurut UUD adalah demokrasi Pancasila. Setiap sila dari lima sila, termasuk Ketuhanan Yang Maha Esa menjadi dasar demokrasi di Indonesia. Oleh karena itu, Negara tidak memisahkan antara urusan agama dengan Negara. Urusan agama menjadi urusan resmi Negara seperti telah dibentuk Kementerian Agama. Maka demokrasi pun tidak lepas dari nilai-nilai agama, tetapi juga bukan Negara agama.

Pengamalan sila Ketuhanan Yang Maha Esa mencakup tanggung jawab bersama dari semua golongan agama dan kepercayaan terhadap Tuhan Yang Maha Esa untuk secara terus menerus dan bersama-sama meletakkan landasan moral, etik dan spiritual yang kokoh bagi pembangunan nasional sebagai pengamalan pancasila. 23

\footnotetext{
${ }^{23}$ Garis-Garis Besar Haluan Negara (GBHN) tahun 1988, Bab IV Pola Umum Pelita kelima, Angka 5a
} 
Adapun kesamaan konsep antara Piagam Madinah dengan Konstitusi Indonesia antara lain :

1. Keduanya mengandung konsep kesamaan adanya ikatan agama dengan negara.

Bedanya, ikatan agama Islam dengan Negara Madinah sangat erat sekali, karena agama Islam dibawa oleh Nabi Muhammad SAW yang bertindak sebagai kepala negara. Ikatan Islam dengan Negara Madinah tampak jelas dalam hal menyelesaikan masalah-masalah kemasyarakatan dan hubungan agama dengan Negara. Berbeda dengan negara Indonesia yang secara rinci dan eksplisit mengatur antara hubungan negara dengan agama. Dilihat dari aspek hukum, Indonesia sangat mirip dengan piagam Madinah karena sumber hukum di Indonesia menyebut Hukum Islam disamping hukum warisan Belanda dan hukum adat.

Dari pembahasan format dan isi konstitusi Madinah dan Indonesia, secara fenomenologi, tampak bahwa nilai-nilai transendental sangat berpengaruh terhadap rumusan dan isi keduanya. Nilai-nilai keimanan dan ketakwaan kepada Tuhan Yang Maha Esa banyak mendasari dan mewarnai kalimat-kalimat isi keduanya.

2. Kebebasan dalam memeluk agama

Kebhinnekaan tercermin dalam konstitusi sebelum Perubahan UUD 1945,ketentuan yang terkait dengan perlindungan terhadap kebhinnekaan tertuang dalam jaminan terhadap kemerdekaan tiap-tiap penduduk untuk memeluk agamanya masing-masing dan untuk beribadat menurut agamanya dan kepercayaannya itu (Pasal 29 Ayat (2) UUD 1945 sebelum perubahan).Pasca Perubahan UUD 1945, jaminan terhadap kebhinnekaan semakin jelas dan kuat, baik berupa hak individu, hak kolektif, maupun terhadap satuan pemerintahan. Ketentuan UUD 1945 yang menjamin kebhinnekaan dalam bentuk hak individu diantaranya adalah Pasal 28E Ayat (1), (2), dan (3); Pasal 28I Ayat (2); dan Pasal 29 Ayat (2). Pasal 28E Ayat (1) menjamin hak setiap orang bebas memeluk agama dan beribadat menurut agamanya. Pasal 28E Ayat (2) menyatakan bahwa setiap orang berhak atas kebebasan meyakini kepercayaan, menyatakan pikiran dan sikap, sesuai dengan hati nuraninya. Pasal 28E Ayat (3) menjamin hak setiap orang atas kebebasan berserikat, berkumpul, dan mengeluarkan pendapat. Pasal 28I Ayat (2) secara tegas menyatakan bahwa "Setiap orang berhak bebas dari perlakuan yang bersifat diskriminatif atas dasar apa pun dan berhak mendapatkan perlindungan terhadap perlakuan yang bersifat diskriminatif itu".

Khusus untuk kemerdekaan beragama dan beribadat, adalah jaminan terhadap kebhinnekaan dalam hal beragama. Hal itu ditegaskan dalam dua 
ketentuan, yaitu Pasal 28E Ayat (1) dan Pasal 29 Ayat (2) UUD 1945. Bahkan, dalam Pasal 28I Ayat (1) UUD 1945 ditegaskan bahwa hak kemerdekaan pikiran dan hati nurani, serta hak beragama merupakan hak asasi yang tidak dapat dikurangi dalam keadaan apapun.

Kebebasan untuk berpegang kepada suatu agama dalam Piagam Madinah juga berlaku bagi Yahudi Bani an-Najjar (pasal 26), Yahudi Bani an-Najjar (pasal 27), Yahudi Bani Sa’idah (pasal 28), Yahudi Bani Jusyam (pasal 29), Yahudi Bani Aws (pasal 30), Yahudi Bani Tsa'labah (pasal 31), Jafnah Bani Tsa’labah (pasal 32), Yahudi Bani Syutaibah (pasa 33), Mawali Tsa'labah (pasal 34), orang-orang dekat atau teman kepercayaan kaum Yahudi (pasal 35).

3. Tugas Melindungi Negara

Tugas melindungi negara diterangkan dalam pasal 39-41, sedangkan dalam UUD diatur dalam pasal 30 ayat 1 Yang berbunyi "Tiap-tiap warga negara berhak dan wajib ikut serta dalam usaha pembelaan negara". Dan ayat 2. Yang berbunyi "Syarat-syarat tentang pembelaan diatur oleh undangundang".

Dalam Piagam Madinah Nabi Muhammad SAW dalam kapasitasnya sebagai Nabi dan kepala negara tidak memaksa untuk mengubah agama. Ia hanya mendakwakan Islam. Soal konversi ke agama Islam tergantung kepada kesadaran mereka. Bahkan Nabi SAW menciptakan kerukunan antar komunitas agama dan keyakinan yang ada. Dalam kaitan ini Fazlur Rahman menyatakan, Piagam itu telah memberi jaminan kebebasan beragama bagi orang-orang Yahudi sebagai suatu komunitas dan mewujudkan kerja sama yang erat dengan kaum muslimin. ${ }^{24}$

\section{Penutup}

Negara Kesatuan Republik Indonesia, bukanlah negara yang berideologikan Islam, tetapi berasaskan Pancasila dan UUD 1945. Namun, itu bukan berarti bahwa negara ini mengabaikan atau bahkan menabrak syari'at Islam. Hal ini didukung dengan bukti bahwa Konstitusi Madinah telah tercermin dalam konstitusi Indonesia. Bentuk konkritnya tercermin dalam butiran pasalpasal UUD 1945. Kedua konstitusi ini mengandung konsep kesamaan adanya ikatan agama dengan negara, kebebasan dalam memeluk agama serta tugas melindungi Negara.

\footnotetext{
${ }^{24} \mathrm{http}: / /$ islahilwathon.blogspot.co.id/2014/06/makalah-fiqih-siyasah-konseppiagam.html
} 


\section{Daftar Pustaka}

Abu Sinn, Ahmad Ibrahim, Manajemen Syariab Sebuah Kajian Historis dan Kontemporer, penerjemah Dimyaudin Djuwaini, judul asli, "Al-Idarah fi alIslam”, Jakarta: Raja Grapindo, 2006

Bashori. H. M. As'ad, Sejarah Kebudayaan Islam, Surabaya: Prima Media, 2008

CD-ROOM, al-Makhtabah asy-Syamilah

HM. Rasyidi, Koreksi tehadap Nurcholish Madjid tentang Sekularisasi, Jakarta: Bulan Bintang, 1972

Garis-Garis Besar Haluan Negara (GBHN) tahun 1988, Bab IV Pola Umum Pelita kelima, Angka 5a

http://www.hidayatullah.com/spesial/ragam/read/2014/11/15/33214/piagam -madinah-konstitu si-tertulis-pertama-di-dunia-1.html

http://agenmakalah. blogspot.co.id/2015/01/pemerintahan-di-masa-nabinegara-madinah. html

http://mafahim-azhari.blogspot.co.id/2008/11/piagam-madinah-tanpa-hukumislam.html

http://islahilwathon.blogspot.co.id/2014/06/makalah-fiqih-siyasah-konseppiagam.html

Ismatullah. Dedy, Gagasan Pemerintahan Modern dalam Konstitusi Madinah, Bandung: Atadbir dan Sahifa, 2006

Ibn Katsir al-Dimasyqy, Abi al-Fida' al-Hafidz, al-Bidayah wa al-Nihayah, Bairut: Dar al-Kutub al-Ilmiah, 2001, Juz III:

Khamis, Muhammad Mun'im, al-Idarah fi Shadr al-Islam, Kairo: Dirasah Muqaranah al-Majlis al-Ala Lisysyu'un al-Islam, 1974

Lings. Martin, Muhammad, Jakarta: Serambi, 2007

M. Echos. John dan Hassan Sadily, Kamus Inggris Indonesia, Jakarta: Gramedia, 2010, Cet ke-29

Madjid, Nurcholish, "Cita-cita Politik Kita", dalam Aspirasi Umat Islam Indonesia, Jakarta: Leppenas, 1983

Sudrajat. Budi, Sejarah Kebudayaan Islam, Jakarta: Yudhistira, 2007

Sabiq, Said, Fiqh as-Sinnah, Bairut: Dar al-Fikr, 1992, Jilid 2 